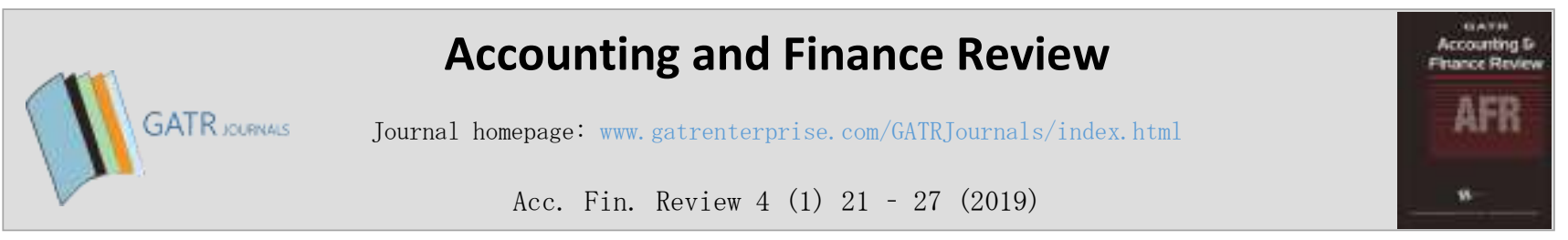

\title{
The Effect of Corporate Governance on Financial Performance in Non-Financial LQ-45 Firms Listed on the Indonesian Stock Exchange from 2012 to 2017
}

\author{
Erika Jimena Arilyn ${ }^{1}$ * Beny, ${ }^{2}$ Emir Kharismar ${ }^{3}$ \\ ${ }^{1,2,3}$ Trisakti School of Management, Jakarta - Indonesia
}

\begin{abstract}
Objective - This research is conducted in order to determine what factors in corporate governance affect the financial performance of a firm.

Methodology/Technique - Financial performance, as the dependent variable, is measured by Return on Asset (ROA), while the independent variables (corporate governance) are measured using Board Independence, Board Size, Dividend, Firm Size, and Financial Leverage. The sampling method used in this research is purposive sampling. The requirements for the sample of this research are the non - financial firms included in LQ-45 from 2012 to 2017 that publish annual reports that are available to the public. The research method used in this paper is a quantitative method. Panel data analysis technique and E-views tools were also used.

Findings - The results indicate that firm size and percentage of board independence has no effect on financial performance, while board size, dividends, and financial leverage all effect financial performance.
\end{abstract}

Novelty - The study adds to the literature of corporate government and firm performance in emerging countries.

Type of Paper: Empirical.

JEL Classification: M40, M48, M49.

Keywords: Board Independence; Board Size; Dividends; Firm Size; Financial Leverage; Financial Performance.

\section{Introduction}

Indonesia continues to strive to improve its positive image, particularly the economic performance of companies operating in Indonesia. Based on the ease of doing business, The World Bank has raised Indonesia's ranking from 109 in 2016 and 91 in 2017 to 72 in 2018. Standard and poor has also upgraded the Indonesia's investment outlook from BB+ in 2016 to investment grade BBB- in 2017 and 2018.

\footnotetext{
* Paper info: Revised: December 11, 2018

Accepted: March 19, 2019

* Corresponding author: Erika Jimena Arilyn

E-mail: erika@stietrisakti.ac.id

Affiliation: Trisakti School of Management, Jakarta - Indonesia
} 
All of these achievements show how international investors are more confident with Indonesia's economic condition and investment opportunities. To support all those achievements, it is necessary to improve quality in all areas of company operations, known as corporate governance, which is used as a tool to introduce internal structures and processes to maintain shareholder trust and gain investor interest. Corporate governance promotes corporate fairness, transparency and accountability (Glossary, 2013 in Adekunle, 2014) and organizations that conduct corporate governance can guarantee its owners and stakeholders will receive a fair return on their investment (Clarkson \& Deck, 1997 in Adekunle, 2014). According to Fama and Jensen (1983) in Rostami et. al., (2016), the structure of the board is the most important aspect of corporate governance that has a large impact on the performance of the board and thus on firm performance.

\section{Literature Review}

\subsection{Dividend Relevance Theory}

According to Miller and Modigliani (1961), in a perfect world, the determination of a firm's value could be seen from its earning power and asset risk where its' policy to distribute its earning to dividends and/or retained earning does not effect this value. However, Gordon and Lintner (1962) argue that dividend payouts affect the firm's value. Gordon and Lintner (1962) have formulated the Dividend Relevance Theory and state that there is, in fact, a direct relationship between the firm's dividends and its' market value.

\subsection{Agency Theory}

Agency Theory assumes that there is a separation between ownership and management. Management might concern themselves with their personal wealth, job security, and fringe benefits; these concerns may cause managers to make decisions that are not consistent with the firm's goal to maximize shareholder wealth (Gitman \& Zutter, 2015:67-68). If there is a conflict of interest between shareholders (principal) and management (agent), agency problem may arise which may create agency costs (the costs of the conflict of interest between stockholders and management). According to Ross et. al. (2015), agency costs can be direct (a corporate expenditure that benefits management but costs the shareholders, and an expense that arises from the need to monitor management actions ) and indirect (a loss of opportunity).

\subsection{Financial Performance}

According to Muwidha et. al. (2013:2), financial performance is the achievement of a firm that issues shares that reflect the financial condition and performance of a company. This is usually measured by using financial ratios based on accounting profits. Gitman and Zutter (2015:130) use return on total assets (ROA), often called return on investment (ROI), to measure the overall effectiveness of management in generating profits with its available assets.

\subsection{Corporate Governance}

\subsubsection{Board Independence}

Rezaee (2009:105) state that the independence of a company's board of directors is essential to the proper and objective functioning of the board however, there is a lack of agreement concerning how to define or recognize this (Monks \& Minow, 2011:257). Indonesia's Financial Service Authority (Otoritas Jasa Keuangan / OJK) Regulation No. 33 of 2014 Article 28 outlines the duties of the board of commissioners to supervise company policies and provide advice to the board of directors. According to Effendi (2016:39-40), independent commissioners are members of the board of commissioners who do not have a relationship with financial, management, share ownerships, and/or family of board's members, both board of directors and and 
board of commissioners, and/or controlling shareholders or relation with banks which could affect their ability to act independently. Rizwan et. al. (2016) shows that board size affects a company's financial performance.

\subsubsection{Board Size}

Solomon (2010) states that board size is an important factor in most corporate governance rating systems that influences the value of the firm (performance). Constraining board size in order to achieve a more effective board seems to be the preferred choice, because a small board size is generally considered to improve the value of the firm because the benefits of increased monitoring by larger boards are out-weighed by poorer communication and decision making abilities of larger groups (Rouf, 2012). Rizwan et. al. (2016:23) states that board size has a negative relationship with financial performance.

\subsubsection{Dividends}

Dividends are payments made by a firm to its owners, either in cash or in stocks, to attract investors and retain exiting shareholders. This is also referred to as the income component of the return on an investment in stock (Ross et. al., 2015). Modigliani and Miller (1961) argue that dividend policies do not remain relevant under the assumption of perfect market conditions. However, Hughes (2008) reveals that dividend policies are relevant in imperfect market conditions. Rizwan et. al., (2016:23) states that there is a significant relationship between a firm's financial performance and its' dividend payout ratio.

\subsubsection{Firm Size}

Firm size is the scale of a firm that describes the size of the firm by calculating the size of its' assets, its' total sales, the average of sales, and the average of its' assets (Ferry \& Jones, 1979). Size refers to the amount of owned and borrowed assets of a firm, and there is a significant though probably not large capital requirements barrier as a result which is likely to have a greater effect on profit rates. Al-Jafari and Samman (2015:309) demonstrate that the size variable positively effect both net profit margin and return on assets.

\subsubsection{Financial Leverage}

Gitman and Zutter (2015:124) formulate financial leverage as a magnification of risk and return through the use of fixed-cost financing, such as debt and preferred stock, an alternative to fund activities in the firm other than issuing shares in the stock market. Al-Jafari and Samman (2015:309) conclude that financial leverage has a negative and statistically significant effect on both net profit margin and return on assets.

\section{Research Methodology}

Purposive sampling is used to gather samples from the source of data with several conditions (Sugiyono, 2015:144) which is fit to some criteria set by the researcher (Sekaran \& Bougie, 2016:248). Therefore, the requirements for the sample of this research are: (a) The company is a part of 45 very liquid firms (LQ-45 firms) listed on the Indonesian Stock Exchange from 2012-2017; (b) The company is from a non-financial industry; and (c) The company publishes its annual reports which are available to the public. This research uses 9 companies and 54 data results in the sample. The data is analysed using analysis of multiple regression. The table below shows the list of the company selected: 
Table 1. Research Samples

\begin{tabular}{|c|c|c|}
\hline No. & Ticker & Company \\
\hline 1 & AALI & Astra Agro Lestari Tbk \\
\hline 2 & ANTM & Aneka Tambang Tbk \\
\hline 3 & ASII & Astra International Tbk \\
\hline 4 & INCO & Vale Indonesia Tbk \\
\hline 5 & INDF & Indofood Sukses Makmur Tbk \\
\hline 6 & KLBF & Kalbe Farma Tbk \\
\hline 7 & PTBA & Tambang Batubara Bukit Asam \\
\hline 8 & TLKM & Telekomunikasi Indonesia Tbk \\
\hline 9 & UNTR & United Tractors Tbk \\
\hline
\end{tabular}

Source: Created by researcher

The equation for the base model is as follows:

$\mathrm{ROA}=$

$\beta_{0}+\beta 1$ Board Independence $+\beta 2$ Board Size $+\beta 3$ Dividend $+\beta 4$ Firm Size $+\beta$ FFinancial Leverage $+\varepsilon$

The dependent variable in this study is Return on Asset, which is the measurement on the overall effectiveness of management in generating profits with its available assets (Gitman \& Zutter, 2015:130). According to Ritwan et. al. (2016:17), ROA is computed by dividing net income to total assets.

Board Independence refers to the board of commissioners in order to adjust into the condition in this country, which is the number of member of board of directors and board of commissioners in a firm (Rizwan et. al., 2016:18). Dividend payout ratio is the measurement of dividend policies which is the percentage of earning in the form of cash paid to shareholders (Rizwan et. al., 2016:18).

Firm size is the size of a firm which is calculated using the amount of assets, sales, average assets, average sales, and is used for several purposes (Al-Jafari \& Samman, 2015:306). Financial leverage is the use of debt that can increase the risk of fixed expense (Al-Jafari \& Samman, 2015:306). Based on the theoretical review and previous research, the model framework for the research is presented in Figure 1 below. 


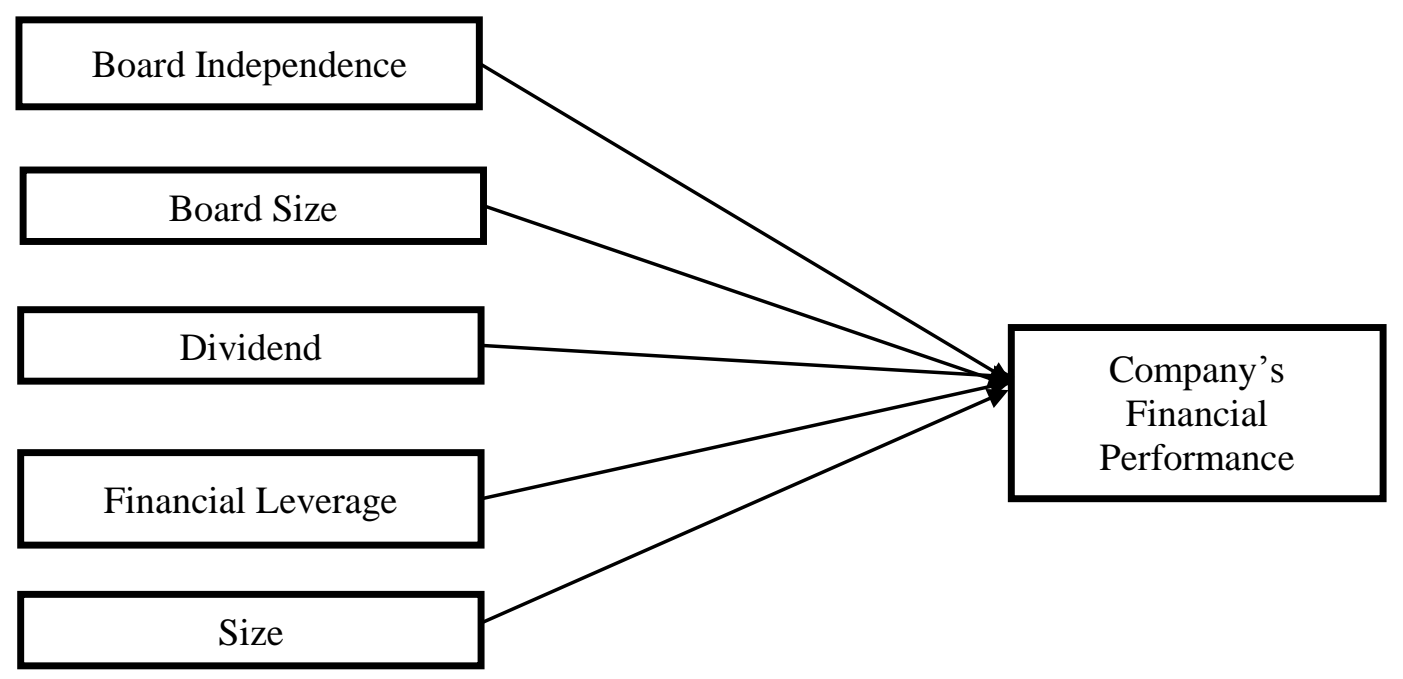

Figure 1. Research Model

\section{Results}

This table below presents the descriptive sample statistics.

Table 2: Descriptive Statistics

\begin{tabular}{|c|cccccc|}
\hline & $\begin{array}{c}\text { Board } \\
\text { Independence }\end{array}$ & Board Size & Dividend & Firm Size & $\begin{array}{c}\text { Financial } \\
\text { Leverage }\end{array}$ & $\begin{array}{c}\text { Return on } \\
\text { Asset }\end{array}$ \\
\hline $\mathbf{N}$ & 54 & 54 & 54 & 54 & 54 & 54 \\
Missing & 0 & 0 & 0 & 0 & 0 & 0 \\
Mean & 0.189381 & 2.626054 & 0.38263 & 16.687347 & 0.354882 & 0.123888 \\
$\begin{array}{c}\text { Std. } \\
\text { Deviation }\end{array}$ & 0.0810563 & 0.5625836 & 0.2401746 & 0.1158775 & 1.4905873 & 0.1053634 \\
Minimum & 0.1 & 0.6989 & 0 & 0.15 & 12.9246 & -0.0475 \\
Maximum & 0.5714 & 3.3322 & 0.768 & 0.62 & 19.1223 & 0.8175 \\
\hline
\end{tabular}

Source: SPSS 16 Processing Result

The result of the statistical test can be seen in hypothesis results shown in Table 3 below.

Table 3: Hypothesis Results

\begin{tabular}{|c|c|c|c|c|}
\hline \multirow{2}{*}{ Model } & \multicolumn{2}{|c|}{ Unstandardized Coefficients } & \multirow{2}{*}{ T } & Sig. \\
\cline { 2 - 3 } & $\mathbf{B}$ & $\begin{array}{c}\text { Std. } \\
\text { Error }\end{array}$ & $\mathbf{t}$ & \\
\hline Constant & 0.282 & 0.205 & 1.375 & 0.173 \\
Board Independence & -0.341 & 0.204 & -1.67 & 0.099 \\
Board Size & -0.128 & 0.056 & -2.293 & 0.025 \\
Dividend & 0.114 & 0.056 & 2.025 & 0.046 \\
Firm Size & 0.019 & 0.02 & 0.925 & 0.358 \\
\hline
\end{tabular}




\begin{tabular}{|l|l|l|l|l|}
\hline Financial Leverage & -0.324 & 0.135 & -2.398 & 0.019 \\
\hline
\end{tabular}
Dependent Variable: ROA
Source: SPSS 16 Processing Results

From the results above, it can be seen that all variables have an effect on financial performance except board independence and firm size. The percentage of board independence does not effect financial performance. This result is not consistent with previous research by Rizwan et. al. (2016) and Effendi (2016:39-40). The results of firm size is also not consistent with previous research by Al-Jafari and Samman (2015:308-309) which shows that firm size has a positive and significant effect on ROA. Further, board size affects company financial performance. This result is consistent with previous research by Rizwan et. al. (2016:23) which shows that board size has a negative effect on financial performance.

Distributing dividends also affects company financial performance. This result is consistent with previous research by Rizwan et. al. (2016:23) which shows that dividends have a relationship with financial performance; this is inconsistent with research by Modigliani and Miller (1961). The comparison in financial leverage affects company financial performance. These results are consistent with previous research by AlJafari and Samman (2015:309) which states that financial leverage has a negative relationship with financial performance.

\section{Discussion}

From the results described above, it is concluded that board independence does not play a role in company performance. However, some scholars have made inconsistent conclusions to this and find that the presence of independent directors on the board would not only result in the good performance of a company, but also encourage better governance (Wallison, 2009 in Fuzi et. al., 2016:464). Fama and Jensen (1983) in Fuzi et. al. (2016:464) state that the higher the number of independent board members, the more this will mitigate any agency problems by monitoring the opportunistic behavior of top management. Research of manufacturing firms listed on the Compustat S \& P 500 by Fuzi reveals a significant positive relationship between a company's performance and pursuing a strategy on cost efficiency however, a different result occurred in 9 liquid companies listed on the Indonesian Stock Exchange. The bigger the board within a company, the less return they can achieve, due to the extensive deliberation and judgment of the board which delays decisions that must be made by company. The market will perceive a dividend payment as a positive signal of a company's financial performance. Since the companies researched in the present paper have a large market capitalization and are very liquid, investors do not consider the size of a firm when making investment decisions. Minimum financial leverage will maximize the financial performance of a company because there is no need to pay the interest and principal on loans.

\section{Conclusion}

This study examines the effect of corporate governance and firm performance of non - financial LQ-45 companies listed on the Indonesian Stock Exchange. The results show that there are three variables of firm governance that affect firm performance. Board size and financial leverage have a negative effect, while dividends have a positive effect. The remaining variables were board independence and firm size which have no effect on firm performance.

The limitations of this research include the lack of information and data access for some of the variables used in this research, the limited number of variables used, and the fact that the number of companies used as the sample did not cover all industries in Indonesia. Future research should use additional data from trusted and legal institutions or directly from the company if possible. Further, the use of more variables might broaden the results of the research from this topic, such as insider ownership, fixed assets, and working capital, Chief Executive Officer (CEO) status and shareholding (ownership) concentration, and firm age for 
independent variables and Return on Equity as the dependent variable. More companies and/or specific industries used as a sample could achieve more accurate results. This study uses LQ - 45 firms from 624 companies in 9 listed industries, including: (1) agriculture, (2) basic industry and chemicals, (3) consumer goods industry, (4) finance, (5) infrastructure, utilities and transportation, (6) mining, (7) miscellaneous industry, (8) property, real estate and building construction, and (9) trade, service, and investment. The results of this research may be different in one or more industries in Indonesia.

\section{References}

Adekunle, Simon Ayo and Aghedo, Enoghayinagbon Maurice (2014). Corporate Governance and Financial Performance of Selected Quoted Companies in Nigeria. European Journal of Business and Management, 6(9), 53 - 60.

Aggarwal, Priyanka (2013). Corporate Governance and Corporate Profitability: Are They Related? - A Study in India Context. International Journal of Scientific and Research Publication, 3(12), 1 - 8.

Al - Jafari, Mohamed Khaled and Al Samman, Hazem (2015). Determinants of Profitability: Evidence from Industrial Companies Listed on Muscat Securities Market. Review of European Studies, 7(11), 303 - 311.

Al - Khazali, Osamah M. and Zoubi, Taisier A. (2005). Empirical Testing of Different Alternative Proxy Measures for Firm Size. The Journal of Applied Business Research, 21(3), 79 - 88.

Arora, Akshita \& Sharma, Chandan (2016). Corporate governance and firm performance in developing countries: Evidence from India. Corporate Governance, 16 (2), 420 - 436.

Effendi, Muh. Arief (2016). The Power of Corporate Governance: Theory and Implementation. Jakarta: Salemba Empat.

Fuzi, Sharifah Faatihah Syed \& Hakim, Syahrina 'Adliana Abdul \& M.K., Julizaerma (2016). Board Independence and Firm Performance. Procedia Economics and Finance, 37 (2016), 460 - 465.

Gitman, Lawrence J., and Chad J. Zutter (2015). Principles of Managerial Finance (14ed.). Harlow: Pearson Education Limited.

Hall, Marshal, and Leonard Weiss (1967). Firm Size and Profitability. The Review of Economics and Statistics, 49 (3), 319-331.

Hasan, Mudassar \& Ahmad, Muhammad Ishfaq \& Rafiq, Muhammad Yasir \& Rehman, Ramiz Ur (2015). Dividend Payout Ratio and Firm's Profitability. Evidence from Pakistan. Theoretical Economics Letters. $441-445$.

Kieschnick, Robert \& Moussawi, Rabih (2018). Firm Age, Corporate Governance, and Capital Structure Choices. Journal of Corporate Finance, 48 (2018), 597 - 614.

Megginson, William L. (1997). Corporate Finance Theory. Boston: Addison-Wesley Educational Publishers Inc.

Monks, A. Robert and Minow, Nell (2011). Corporate Governance. John Wiley \& Sons, USA.

Muwidha, Muhammad, Edi Winarto, Imam Mulyono (2013). Comparative Test Analysis of the Effect of Financial Performance on Company Values Between Food Beverage and Automotive Allied Product Group at PT. Indonesia Stock Exchange. Proceeding Pro Poltek Dissemination of Research Result: 2-6.

Rezaee, Zabihollah (2009). Corporate Governance and Ethics. John Wiley \& Sons, USA.

Rizwan, Muhammad, Humera Asrar, Noman Alam Siddiqui, Waqaruddin Usmani (2016). The Impact of Corporate Governance on Financial Performance: An Empirical Investigation. International Journal of Management Sciences and Business Research, 5 (9), 11-27.

Ross, Stephen A., Randolph W. Westerfield, and Jeffrey Jaffe (2015). Corporate Finance (10 ed.), Asia Global Edition. Asia; McGraw-Hill Education (Asia).

Rostami, Shoeyb \& Rostami, Zeynab \& Kohansal, Samin. The Effect of Corporate Governance Components on Return on Assets and Stock Return of Companies Listed on Tehran Stock Exchange. Procedia Economics and Finance, 36 (2016), $137-146$.

Rouf, Md. Abdur (2011). The Relationship between Corporate Governance and Value of the Firm in Developing Countries: Evidence from Bangladesh. The International Journal of Applied Economics and Finance, 5 (3), 237 - 244.

Sekaran, Uma, and Roger Bougie (2016). Research Methods for Business: a skill building approach. Chichester: John Wiley \& Sons Ltd.

Solomon, Jill (2010). Corporate Governance and Accountability. Chichester: John Wiley \& Sons Ltd.

Sugiyono (2014). Business Research Methodology. Bandung: Alfabeta

Tricker, Bob (2015). Corporate Governance Principles, Policies, and Practices (3ed.). Oxford: Oxford University Press. 